\title{
A new species of the genus Paradoxecia Hampson, 1919 (Lepidoptera: Sesiidae) from West Malaysia with a catalogue of the genus
}

\author{
Новый вид рода Paradoxecia Hampson, 1919 (Lepidoptera: Sesiidae) \\ из Западной Малайзии с каталогом рода
}

\author{
O.G. Gorbunov \\ О.Г. Горбунов
}

\begin{abstract}
A.N. Severtsov Institute of Ecology and Evolution, Russian Academy of Sciences, Leninsky prospekt 33, Moscow 119071, Russia. E-mail: gorbunov.oleg@mail.ru

Институт проблем экологии и эволюции им. А.Н. Северцова РАН, Ленинский проспект 33, Москва 119071, Россия.
\end{abstract}

KEY WORDS. Lepidoptera, Tinthiinae, clearwing moths, new species, new synonym, Oriental Region.

КЛЮЧЕВЫЕ СЛОВА. Lepidoptera, Tinthiinae, бабочки-стеклянницы, новый вид, новый синоним, Ориентальный регион.

ABSTRACT. A new species, Paradoxecia tuzovi sp.n. from the state of Pahang, West Malaysia, is described and figured. The type series of the new species was collected with using artificial sex attractant. Types are deposited in the collections of the A.N. Severtsov Institute of Ecology and Evolution of the Russian Academy of Sciences, Moscow, Russia. The female and the larval host plant are still unknown. This is the first record of the genus to the continental part of Malaysia. Based on the female genitalia, as well as the external morphology, it has been established that Paradoxecia pieli Lieu, 1935 as a junior synonym for Aegeria gravis Walker, 1865, syn.n. An annotated catalogue of the genus Paradoxecia Hampson, 1919 is provided.

РЕЗЮМЕ. Приведено описание нового вида, Paradoxecia tuzovi sp.n. из штата Паханг, Западная Малайзия. Типовая серия нового вида была собрана с помощью искусственных половых аттрактантов. Типы хранятся в коллекции Института проблем экологии и эволюции им. А.Н. Северцова Российской академии наук в Москве. Самка и кормовое растение гусениц неизвестно. На основании гениталий самки, а также внешней морфологии установлено, что Paradoxecia pieli Lieu, 1935 является младшим синонимом Aegeria gravis Walker, 1865, syn.n. Приведён аннотированный каталог рода Paradoxecia Hampson, 1919.

\section{Introduction}

Our knowledge of the structure of the Oriental region's clearwing moth fauna has grown significantly over the past quarter century. During this time, many very interesting and important works have been published about Sesiidae in Laos and Thailand [Arita, Gorbunov, 1995b, 1996a,b; Gorbunov, Arita, 1995e; Gorbunov, 2015b, 2021b-d; Skowron Volponi, 2019, 2020; etc.], Vietnam and Nepal [Gorbunov, Arita, 1995a-d, 1996a, 1997, 1999, 2000a, 2005, 2018b, 2019, 2020a-c; Arita, Gorbunov, 1995a-c, 2000a-c, 2002a, 2003; etc.], South China and Taiwan [Arita, Gorbunov, 1998, 2001a, 2002a; Kallies, Arita, 1998a; Xu et al., 1999, 2015, 2019; Gorbunov, Arita, 2000b, 2001a,b; 2002a; Kallies et al., 2014a, b; Arita et al., 2018; etc.], Malaysia and Indonesia [Gorbunov, Kallies, 1998; Arita et al., 2003; Gorbunov, Arita, 2005, 2015, 2018a; Gorbunov, 2014, 2015a, 2016, 2018, 2020, 2021a; Skowron et al., 2015; Skowron Volponi, Volponi, 2017, etc.], and the Philippines [Gorbunov, Kallies, 1998; Kallies, Arita, 1998b].

Undoubtedly, the recently published works with illustrations of types of Chinese and Oriental Sesiidae will be of great help in understanding the clearwing moths of the Oriental region [Arita et al., 2021a, b].

As for genus Paradoxecia Hampson, 1919, a very detailed nomenclature history with a key based on external characters to the species of this taxon was published quite recently [Yu et al., 2019]. The authors attributed 16 species to the genus, including three species that were described as new. After analyzing all the available information, including illustrative material on both male and female genitalia, I concluded that genus Paradoxecia as it is currently adopted, is heterogeneous. Superficially, as well as in the structure of both male and female genitalia, this genus should be divided into at least two or even three taxa of the genus group

How to cite this article: Gorbunov O.G., 2021. A new species of the genus Paradoxecia Hampson 1919 (Lepidoptera, Sesiidae) from West Malaysia // Russian Entomol. J. Vol.30. No.3. P.328-335. doi: 10.15298/ rusentj.30.3.11 
level. Unfortunately, the lack of sufficient material does not allow me to do this formally right now. Besides this, I believe that Aegeria gravis Walker, 1865 and Paradoxecia pieli Lieu, 1935 are conspecific (see below) and establish $P$. pieli as a junior synonym for $P$. gravis, syn.n.

The present paper presents the description of a new species, Paradoxecia tuzovi sp.n. In addition, I provide an annotated catalogue of the genus Paradoxecia, which contains updated taxonomic information including references to the original descriptions, information on name-bearing types, complete bibliographies, data on flight period and distribution of all 16 species.

The descriptions of the specimens were made using a Leica EZ4 stereomicroscope with LED illumination. All imagines of the type series were taken with a Sony ${ }^{\circledR}$ $\alpha 450$ DSLR camera equipped with a Minolta ${ }^{\circledR} 50 \mathrm{~mm} \mathrm{f} /$ 2.8 Macro lens. The genitalia were photographed using a Keyence ${ }^{\circledR}$ BZ-9000 Biorevo Fluorescence Microscope. The processing of all illustrations was finalized with Adobe ${ }^{\circledR}$ Photoshop ${ }^{\circledR}$ CC2020 software.

All labels of the holotype are cited verbatim. The labels of geographical data, imaging data and genitalia preparation numbers are printed on white paper, but the type label of the holotype and paratypes are printed on red paper. Each label is separated by a semicolon "," lines in a label are separated by a slash "/". All pictures of specimens are labeled with a number, consisting of letters and digits: name of the family, two consecutive digits separated by an n-dash and a year following the m-dash (e.g. SESIIDAE pictures Nos 0279-0280-2021). These letter and digit codes correspond to the numbering system of the figured specimens in the author's archive. The genitalia preparation is stored in a microtube with glycerol and pinned under the specimen. The dissected genitalia are equipped with the corresponding number placed in the microtube. This number as a label (e. g. Genitalia preparation No OG-017-2021) is pinned under the specimen and listed in the author's archive.

The material studied or mentioned herein is deposited in the following collections abbreviated in the text as follows:

BMNH - the Natural History Museum (formerly the British Museum (Natural History)), London, UK;

COGM — the A.N. Severtsov Institute of Ecology and Evolution of the Russian Academy of Sciences, Moscow, Russia;

ZFMK - Zoologisches Forschungsmuseum Alexander Koenig, Bonn, Germany;

MHNG - Muséum d'histoire naturelle de la Ville de Genève, Genève, Switzerland;

NRMS - Naturhistoriska riksmuseet, Stockholm, Sweden;

NSMT — the National Museum of Nature and Science, Tsukuba, Tokyo (formerly Natural Science Museum Tokyo), Japan;

SCAU — the Department of Entomology, South China Agricultural University, Guangzhou, Guangdong, China.

\section{Taxonomic account}

Paradoxecia tuzovi O. Gorbunov, sp.n. Figs $1-10$.

MATERIAL. Holotype $\sigma^{7}$ (Figs 1-2) with labels: "W. Malaysia, Pahang, / Genting Highland, 800-1000 m, / $03^{\circ} 22^{\prime} \mathrm{N}, 101^{\circ} 47^{\prime}$ E, / 17-23.X.2010, / V. Tuzov leg." (white); "SESIIDAE / Pictures Nos / 0279-0280-2021 / Photo by O. Gorbunov" (white); "HOLOTYPUS O / Paradoxecia tuzovi / O. Gorbunov, 2021 / O. Gorbunov des., 2020" (red) (COGM).

Paratypes $6 \mathrm{O}^{T} \mathrm{O}^{T}$ (Figs 3-6), same locality and date, V. Tuzov leg. (Sesiidae pictures Nos 0269-0278-2021), 1 O$^{7}$ with genitalia preparation No OG-017-2021 (Figs 7-10) (COGM).

DESCRIPTION. Male (holotype) (Figs 1-2). Alar expanse $26.1 \mathrm{~mm}$; body length $11.9 \mathrm{~mm}$; forewing $12.0 \mathrm{~mm}$; antenna $5.5 \mathrm{~mm}$.

Head with antenna black with dark greenish-blue sheen; scapus grey-brown with blue-purple sheen; frons ventrally pale lemon yellow, but remaining part entirely covered with scales of vertex; basal joint of labial palpus lemon yellow, mid and apical joints whitish; vertex grey-brown with greenish-bronze sheen; pericephalic hairs whitish with a few greybrown scales dorsally.

Thorax with patagia grey-brown with blue-violet sheen and a few lemon yellow scales laterally; tegula grey-brown with greenish-violet sheen, a few lemon yellow scales anteriorly at inner margin and narrow lemon yellow exterior and posterior margins; mesothorax grey-brown with greenishviolet sheen; metathorax lemon yellow with a few greybrown scales medially; pro- and mesothorax laterally mixed with grey-brown with bright violet sheen and lemon yellow with golden hue scales; metathorax laterally completely lemon yellow with golden hue; posteriorly both metepimeron and metameron smooth scaled lemon yellow with golden hue.

Legs with neck plate yellowish; fore coxa lemon yellow with golden hue and narrow grey-brown interior and posterior margins; fore femur externally lemon yellow with an admixture of individual grey-brown scales, internally entirely lemon yellow with golden hue; fore tibia externally mixed with grey-brown, dark yellow and lemon yellow scales, internally entirely lemon yellow with golden hue; fore tarsus greybrown with bronze sheen and an admixture of a few dark yellow scales on basal tarsomere; mid coxa pale yellow with a few lemon yellow scales anteriorly; mid femur lemon yellow with golden hue and a few grey-brown scales exteriorly; mid tibia and spurs entirely lemon yellow with golden hue; basal tarsomere of mid tarsus lemon yellow with golden hue, remaining tarsomeres grey-brown with bronze sheen mixed with lemon yellow scales both internally and ventrally; hind coxa pale yellow with a few lemon yellow scales anteriorly; hind femur lemon yellow with golden hue and a narrow greybrown anterior margin; hind tibia lemon yellow with golden hue and with an admixture of grey-brown scales with bluebronze sheen dorsally both from base of tibia to base of mid spurs and distally; spurs whitish; three basal tarsomeres of hind tarsus each dorsally grey-brown with blue-bronze sheen and a few dark yellow scales distally, ventrally entirely lemon yellow with golden hue, two distal tarsomeres yellowish.

Forewing dorsally black with greenish-violet sheen and a small lemon yellow spot at base; costal margin dark brown with violet sheen; CuA-stem, anal margin, discal spot and veins within external transparent area dark brown with bronze sheen; discal spot narrow and small between bases of veins $\mathrm{M}_{2}-\mathrm{CuA}_{1}$; transparent areas well-developed but densely covered with hyaline scales with brownish hue; external transparent area long and narrow between veins $\mathrm{M}_{1}-\mathrm{CuA}_{1}$; posterior 
transparent area long, distinctly exceeding level of discal spot; outer margin undeveloped; cilia dark brown with bronze sheen; ventrally opaque parts dark brown with bronze-violet sheen and a few yellow scales; cilia dark brown with bronze sheen.

Hindwing transparent but covered with sparse hyaline scales with brownish hue; veins narrowly dark brown with bronze sheen; both discal spot and outer margin undeveloped; cilia dark brown with bronze sheen.

Abdomen wasp-waisted: segments 1 and 2 slightly narrowed, segments 3-5 gradually broadened and segments 6-8 gradually narrowed; dorsally tergite 1 dark brown with greenishviolet sheen medially and yellow laterally; tergites $2-4$ each dark brown with greenish-violet sheen and a narrow yellow stripe cranially; tergites 5-8 dark brown with bronze-violet sheen, tergites 5-7 each with a narrow yellow stripe caudally; ventrally sternites $1+2-4$ each white with an admixture of individual lemon-yellow scales; sternites 5-8 each lemon yellow with a few white scales; anal tuft extremely small yellow.

Male genitalia (paratype) (genital preparation No OG017-2021) (Figs 7-10).
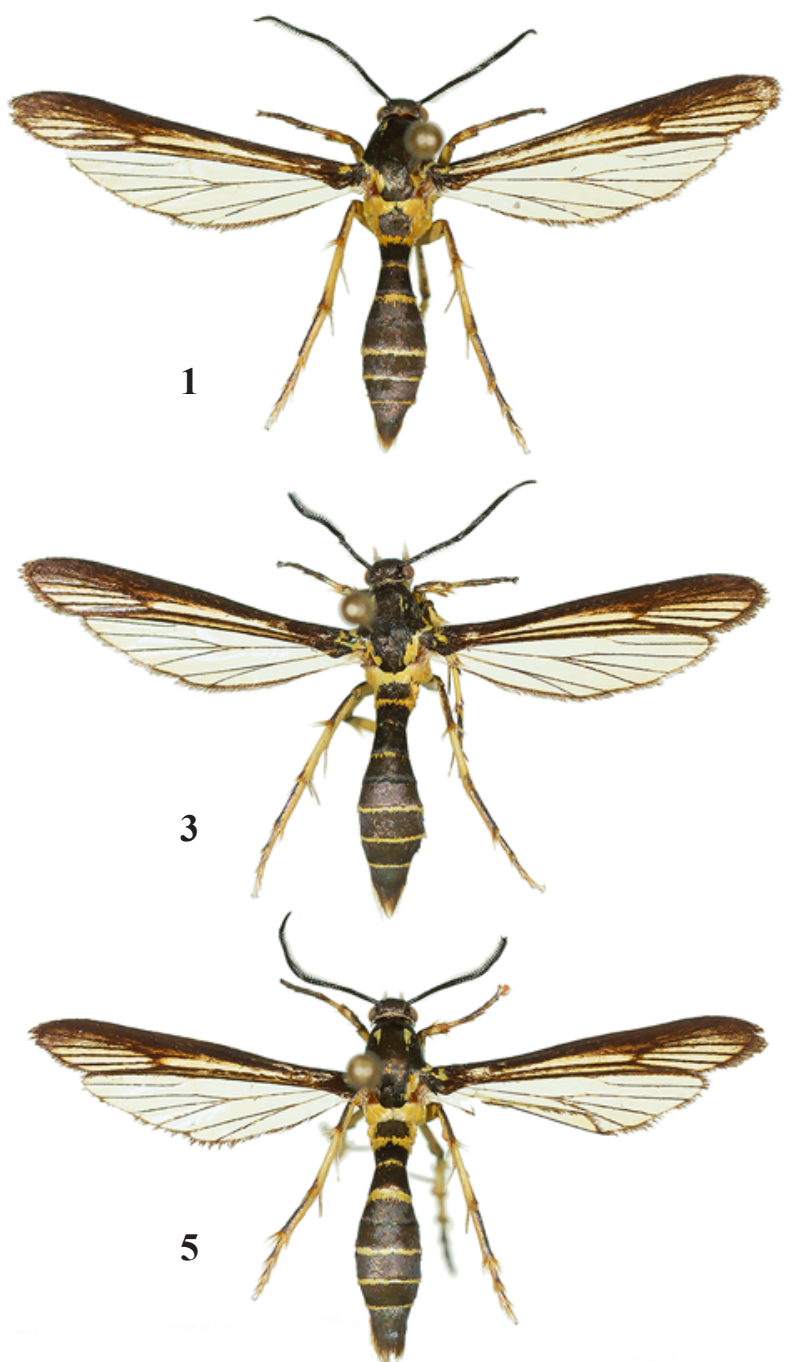

Figs 1-6. Variability of Paradoxecia tuzovi O. Gorbunov, sp.n.: 1-2 - holotype, alar expanse $26.1 \mathrm{~mm}$, Sesiidae picture Nos 02790280-2021;3-4 - paratype, alar expanse $25.4 \mathrm{~mm}$, Sesiidae picture Nos 0273-0274-2021; 5-6 - paratype, alar expanse 25.0 mm, Sesiidae picture Nos 0277-0278-2021; 1, 3, 5 - dorsal view; 2, 4, 6 - ventral view.

Рис. 1-6. Изменчивость Paradoxecia tuzovi O. Gorbunov, sp.n.: 1-2 - голотип, размах крыльев 26,1 мм, Sesiidae снимки №№ 0279-0280-2021; 3-4 - паратип, размах крыльев 25,4 мм, Sesiidae снимки №№ 0273-0274-2021; 5-6 - паратип, размах крыльев 25,0 мм, Sesiidae снимки №№ 0277-0278-2021; 1, 3, 5- сверху; 2, 4, 6 - снизу.

Female. Unknown.

INDIVIDUAL VARIABILITY. Slightly varying in the number of lemon yellow scales on the thorax and yellow scales on the abdomen (Figs 1-6). Besides this, this new species is somewhat variable in individual size: alar expanse $25.0-26.1 \mathrm{~mm}$; body length $11.8-12.2 \mathrm{~mm}$; forewing $11.7-$ $12.0 \mathrm{~mm}$; antenna $5.2-5.5 \mathrm{~mm}$.

DIFFERENTIAL DIAGNOSIS. Superficially this new species is somewhat similar to $P$. radiata Kallies, 2002, but it differs by the conformation of the forewing (forewing covered with light yellow-brown semitransparent scales; veins marked by dense brown scales; common M-stem strongly reduced but clearly marked by a row of brown scales in $P$. radiata; compare Figs 1, 3 and 5 with fig. 1 in Kallies, 2002), by the colouration of the hind leg (hind coxa brownish-grey; hind femur externally brownish-grey with a yellow posterior margin; hind tibia fuscous, ventrally and medially yellow; spurs yellow; hind tarsus yellow with fuscous basal tarsomere dorsally in the species compare, $v s$. hind femur lemon yellow with golden hue and a narrow grey-brown anterior margin; hind tibia lemon
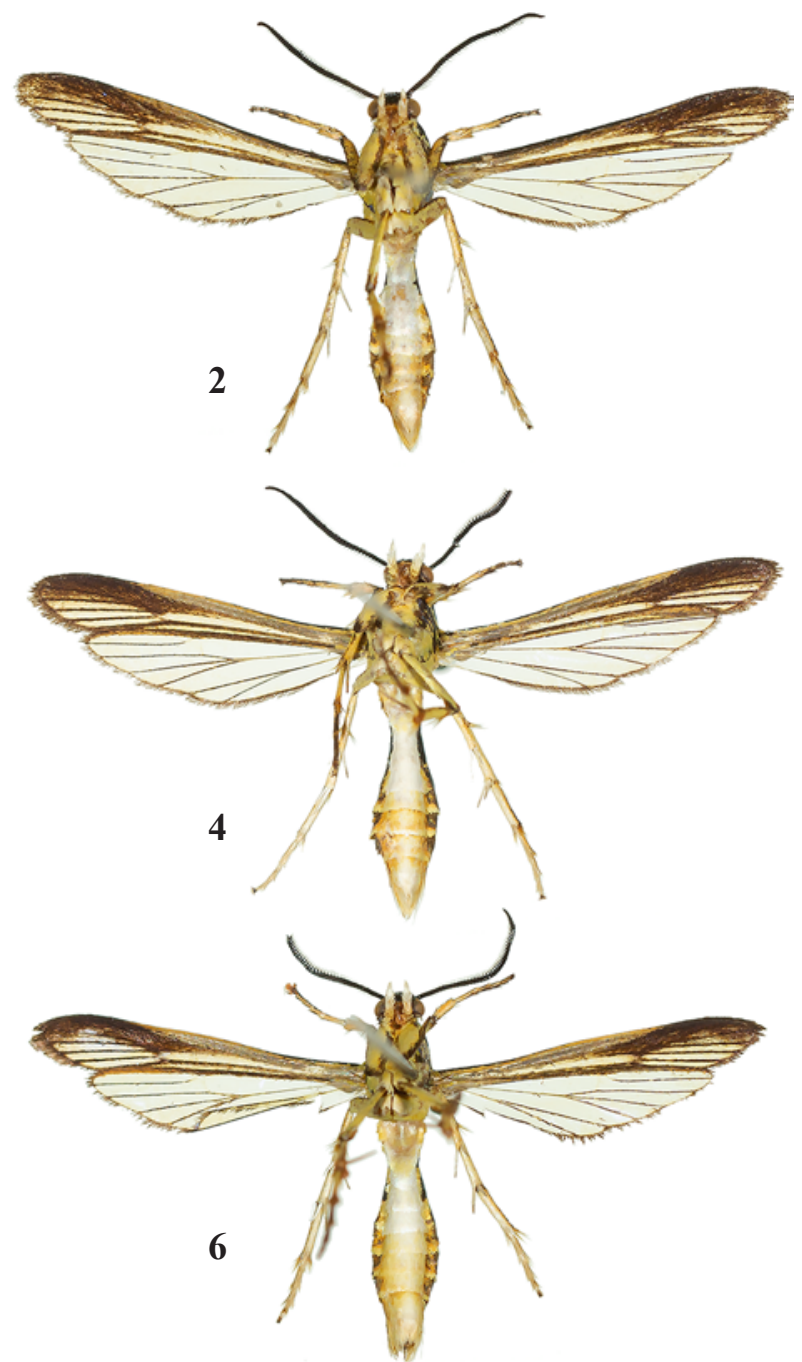
yellow with golden hue and with an admixture of grey-brown scales with blue-bronze sheen dorsally both from base of tibia to base of mid spurs and distally; spurs whitish; three basal tarsomeres of hind tarsus each dorsally grey-brown with bluebronze sheen and a few dark yellow scales distally, ventrally entirely lemon yellow with golden hue, two distal tarsomeres yellowish in $P$. tuzovi sp.n.) and abdomen (dorsally tergite1 yellow with a few black scales; tergites 2-6 each blackish-grey; tergites 4-5 each with a narrow yellow stripe distally; ventrally pale yellow; sternites 6-7 each with an admixture of gray scales; anal tuft yellow-grey medially in $P$. radiata; compare Figs $1-6$ with figs 1 and 2 in Kallies, 2002). By the stricture of the aedeagus in the male genitalia $P$. tuzovi sp.n. is closely related to P. myrmekomorpha (Bryk, 1947), P. dizona (Hampson, 1919), and P. fukiensis O. Gorbunov et Arita, 1997, but it can be distinguished from all of them by the colouration of various parts of the body, especially by the absent of orange or yellow-orange scales on the abdomen.

BIONOMICS. The larval host plant is unknown. The type series was collected in the second half of October with help of unspecific artificial sex pheromones.

HABITAT. The type series was collected at the border of Upper dipterocarp forest at 800-1000 m a.s.l. with Shorea sp., Dipterocarpus sp. (Dipterocarpaceae), Agathis borneensis Warb. (Araucariaceae) and Calophyllum sp. (Clusiaceae) as dominant species.

DISTRIBUTION. The new species is known only from the type locality in the state of Pahang, West Malaysia.

ETHYMOLOGY. This new species is named after my friend Dr. Vasily K. Tuzov, a great expert on Papilionoidea of the world fauna, who collected the type series of this new species.

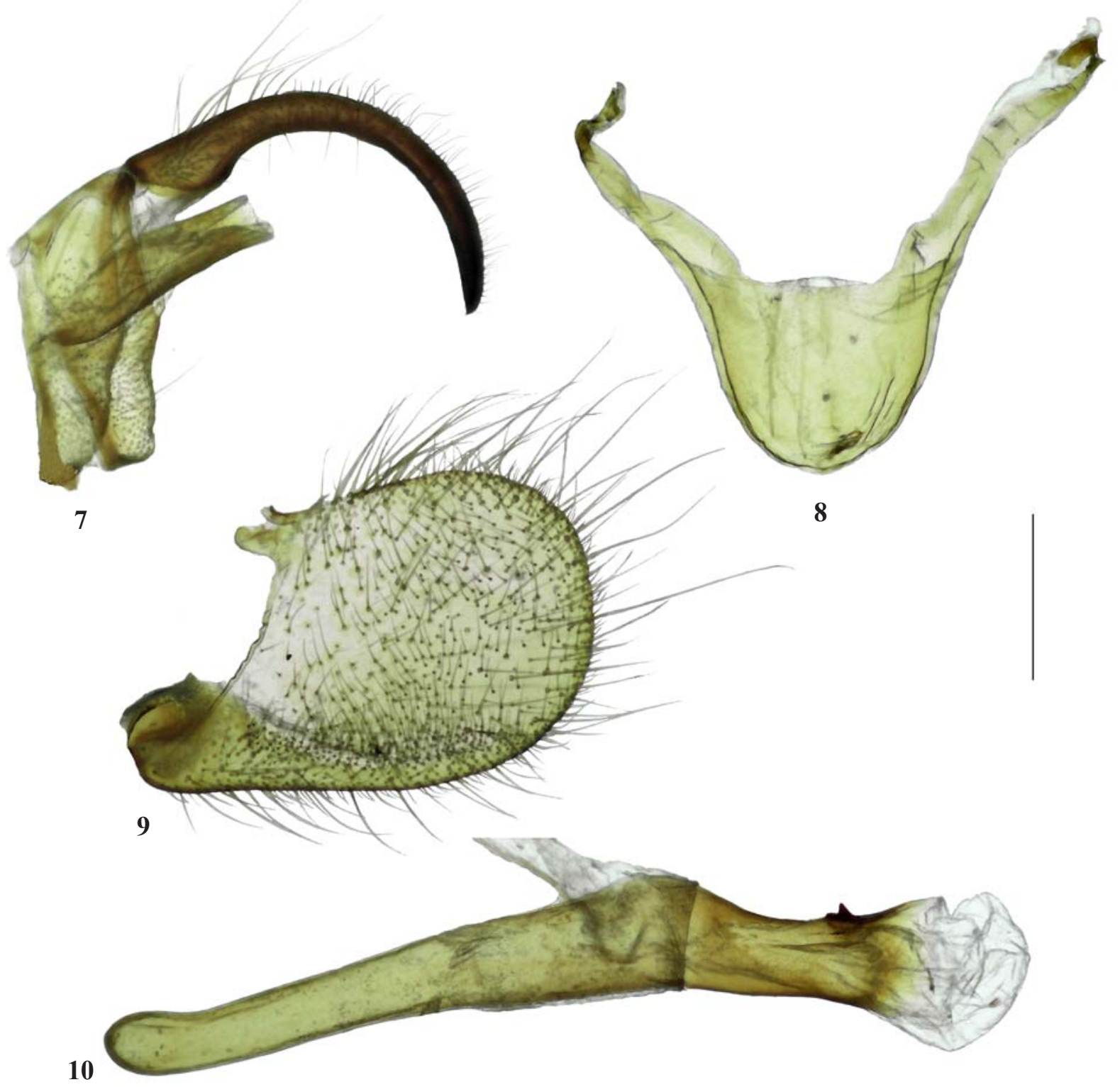

Figs 7-10. Male genitalia of Paradoxecia tuzovi O. Gorbunov, sp.n. Genital preparation No OG-017-2021: 7 - tegumen-uncus complex; 8 - valva; 9 - saccus; 10 - aedeagus. Scale bar: $0.5 \mathrm{~mm}$.

Рис. 7-10. Гениталии самца Paradoxecia tuzovi O. Gorbunov, sp.n. Препарат гениталий № OG-017-2021: 7 — тегумен-ункус комплекс; 8 - вальва; 9 - саккус; 10 - эдеагус. Масштаб: 0,5 мм. 
Catalogue of the genus Paradoxecia Hampson 1919

Paradoxecia Hampson, 1919

“Gen. Paradoxecia nov." - Hampson, 1919: 51 (key), 114. Type species: Aegeria gravis Walker, 1865, by original designation

= "Genus Paranthrenina m. (nov. gen.)." - Bryk, 1947: 106. Type species: Paranthrenina myrmekomorpha Bryk, 1947, by original designation.

LITERATURE. Dalla Torre, Strand, 1925: 180 (Paradoxecia); Gaede, 1933: 797 (Paradoxecia); Lieu, 1935: 191 (Paradoxecia) Naumann, 1971: 22 (Paranthrenina), 22, 55 (Paradoxecia); Heppner, Duckworth, 1981: 21 (Paradoxecia), 24 (Paranthrenina); Fletcher, Nye, 1982: 118 (Paradoxecia), 119 (Paranthrenina); Gorbunov, Arita, 1997: 60 (Paradoxecia); Spatenka et al., 1999: 49 (Paradoxecia); Kallies, Arita, 2001: 214 (Paradoxecia); Gorbunov, Arita 2001c: 17 (Paranthrenina); Pühringer, Kallies, 2004: 7 (Paradoxe cia); Yu et al., 2019: 262 (Paradoxecia); Xu et al., 2019: 29 (key), 35 (Paradoxecia); Pühringer, Kallies, 2021 (Paradoxecia).

RANGE. Oriental realm from North-eastern India (Meghalaya) in the west to the South-western Japan (Okinawajima) in the east and from Central China (Jiangsu and Hubei) in the north and Malaysia (Sarawak) in the south.

Paradoxecia beibengensis Yu et Kallies, 2019

"Paradoxecia beibengensis Yu et Kallies sp. nov." - Yu et al., 2019: 264, 268 (key), figs 5, 6, 9. Type locality: "China, Tibet autonomous region, Medog county, Beibeng, $29^{\circ} 14^{\prime} 11.28^{\prime \prime} \mathrm{N}, 9^{\circ}$ 09' 51.52' E, ...”. Holotype $\sigma^{\prime \prime}$ (SCAU).

LITERATURE. Pühringer, Kallies, 2021 (Paradoxecia beibengensis).

FLIGHT PERIOD. The holotype was collected on the $25^{\text {th }}$ July.

HOST PLANT. Unknown.

DISTRIBUTION. It is only known from the type locality in Tibet, China.

REMARKS. The female in unknown.

Paradoxecia chura Arita, Kimura et Owada, 2009

"Paradoxecia chura sp. nov." - Arita et al., 2009: 189, Fig. 1. Type locality: “... Is. Okinawa-jima, Okinawa-ken, Nakijin-son, Oppadake, ...". Holotype or (NSMT).

LITERATURE. Yu et al., 2019: 267 (key) (Paradoxecia chura); Pühringer, Kallies, 2021 (Paradoxecia chura).

FLIGHT PERIOD. The holotype was collected on the $12^{\text {th }}$ September.

HOST PLANT. Unknown.

DISTRIBUTION. It is only known from the type locality in the island of Okinawa, Japan.

REMARKS. The female is unknown and the male genitalia have not yet been investigated.

Paradoxecia dizona (Hampson, 1919)

"Trichocerota dizona n. sp." - Hampson, 1919: 117. Type locality: "Assam, Khásis, ..." [= India: Meghalaya, Shillong Plateau, Khasi Hills]. Holotype + (BMNH).

LITERATURE. Dalla Torre, Strand, 1925: 184 (Trichocerota dizona); Gaede, 1933: 799, pl. 94, row i (Trichocerota dizona); Heppner, Duckworth, 1981: 22 (Trichocerota dizona); Kallies, Arita, 2001: 189, 219, figs 22, 23, 39, 52 (Paradoxecia dizona) Pühringer, Kallies, 2004: 7 (Paradoxecia dizona); Arita et al., 2018: 8, pl. 1, fig. 9 (Paradoxecia dizona); Yu et al., 2019: 268 (key) (Paradoxecia dizona); Pühringer, Kallies, 2021 (Paradoxecia dizona); Arita et al., 2021b: 8, figs 23a-b (Paradoxecia dizona).

FLIGHT PERIOD. The holotype was collected in July. Specimens from Vietnam were catch in May and June. HOST PLANT. Unknown.
DISTRIBUTION. It is known from North-eastern India, South China and North Vietnam.

Paradoxecia fukiensis O. Gorbunov et Arita, 1997

"Paradoxecia fukiensis sp. n." - Gorbunov, Arita, 1997: 61 (key), 65, figs 5-6, 9, 10a-d. Type locality: "China, Fukien, Kuatun, $2300 \mathrm{~m}, 27-40 \mathrm{~N}, 117-40 \mathrm{E}, . . . ”$ [= China: Fujian, Wuyishan, Guadun]. Holotype + (ZFMK).

LITERATURE. Pühringer, Kallies, 2004: 7 (Paradoxecia fukiensis); Yu et al., 2019: 268 (key) (Paradoxecia fukiensis); Pühringer, Kallies, 2021 (Paradoxecia fukiensis)

FLIGHT PERIOD. The type series was collected in June. HOST PLANT. Unknown.

DISTRIBUTION. It is only known from the type locality in the province Fujian, China.

Paradoxecia gravis (Walker, 1865*)

“Aegeria gravis." - Walker, 1865 ["1864”]: 12). Type locality: "... North China." [= China: environs of Shanghai (?)]. Holotype + (BMNH).

= "Paradoxecia pieli n. sp." — Lieu, 1935: 185, pls I-V. Type locality: “... Kashing; ... Kon-Zen-Chiao, Hang-hsien, Hai-ning, and, Chang-an." [= China: Zhejiang province, Hangzhou, Jiaving, Haining]. Holotype $\sigma^{7}$ (probably lost). Syn.n.

LITERATURE. Hampson, 1919: 114 (Paradoxecia gravis); Dalla Torre, Strand, 1925: 180 (Paradoxecia gravis); Gaede, 1933: 797 (Paradoxecia gravis); Naumann, 1971: 55, figs 18, 57, 172 (Paradoxecia gravis); Heppner, Duckworth, 1981: 22 (Paradoxecia gravis, Paradoxecia pieli); Spatenka et al., 1993: 85 (Paradoxecia gravis); Gorbunov, Arita, 1997: 61, figs 1, 2 (Paradoxecia gravis), 61 (key), 62, fig. 3 (Paradoxecia pieli); Špatenka et al., 1999: 50, pl. 2, fig. 15, text-fig. 285 (Paradoxecia gravis); Pühringer, Kallies, 2004: 7 (Paradoxecia gravis, Paradoxecia pieli); Arita et al., 2018: 8, pl. 1, fig. 12 (Paradoxecia gravis); Yu et al., 2019: 267 (key) (Paradoxecia pieli), 268 (key) (Paradoxecia gravis); Xu et al., 2019: 35 (key), 36 (Paradoxecia gravis, Paradoxecia pieli); Pühringer, Kallies, 2021 (Paradoxecia gravis, Paradoxecia pieli); Arita et al., 2021b: 8 , figs $22 \mathrm{a}-\mathrm{b}$ (Aegeria gravis), 8, figs 24a-d (Paradoxecia pieli).

FLIGHT PERIOD. The holotype of $P$ gravis was caught in August ["54.8."], but the specimens of the type series of $P$. pieli were emerged from pupae between June $20^{\text {th }}$ and July $12^{\text {th }}$.

HOST PLANT. Larvae of $P$. pieli live inside twigs of Morus sp., Moraceae.

DISTRIBUTION. It is known from the provinces of Jiangsu, Zhejiang, Sichuan, Guizhou, Fujian, Guangdong and, possible, environs of Shanghai, China.

REMARKS. 1. The holotype of $P$. gravis was described from "North China", which in the middle of the 19th century for the British, during the Opium Wars, could not have been located north of the Shanghai region. 2. P. pieli was described on the basis of 17 males (holotype and 16 paratypes) and 11 females (allotype and 10 paratypes) bred from larvae collected inside the twigs of cultivated mulberry trees (Morus sp., Moraceae) from at least five localities in Zhejiang province. Unfortunately, the author did not indicate from which particular locality the holotype originated, and its very probable loss does not allow establishing the exact type locality. 3. Unfortunately, the genitalia of the holotype of $P$. gravis are not studied, but at least the genitalia of two females, which are attributed to this species, were studied [Naumann, 1971: fig. 172; Špatenka et al., 1999: fig. 285] and I consider these images to be completely consistent with the images presented in the original description of $P$. pieli [Lieu, 1935: pl. III, figs 18-20]. The original descriptions, as well as photographs of the types of these two taxa, allow me to conclude that Paradoxecia pieli Lieu, 1935 is a junior synonym of Aegeria gravis Walker, 1865, syn.n.

* According to Sherborn, the actual date of publication of the Supplement of the XXXI part of the List of the specimens of Lepidopterous Insects in the collection of the British Museum is February $11^{\text {th }}, 1865$ [Sherborn, 1934]. 
Paradoxecia karubei Kallies et Arita, 2001

"Paradoxecia karubei sp. nov." - Kallies, Arita, 2001: 189, 218, figs 21, 51. Type locality: "N. Vietnam, Ninh Binh Prov., Gia Vien, Cuc Phuong, $370 \mathrm{~m}, . .$. . Holotype + (NSMT).

LITERATURE. Pühringer, Kallies, 2004: 7 (Paradoxecia karubei); Yu et al., 2019: 268 (key) (Paradoxecia karubei); Pühringer, Kallies, 2021 (Paradoxecia karubei) May.

FLIGHT PERIOD. The type series was collected in April-

HOST PLANT. Unknown.

DISTRIBUTION. It is known from two localities in North Vietnam.

REMARKS. The male is unknown.

Paradoxecia kishidai Yu et Arita, 2019

"Paradoxecia kishidai Yu et Arita sp. nov." - Yu et al., 2019: 262, figs 1, 2, 7. Type locality: "China, Hubei Province, Shennongjia, Songbai town, $31^{\circ} 44^{\prime} 21.30^{\prime \prime} \mathrm{N}, 110^{\circ} 41^{\prime} 15.62^{\prime \prime} \mathrm{E}, \ldots$. Holotype $\sigma^{7}$ (SCAU).

LITERATURE. Yu et al., 2019: 268 (key) (Paradoxecia kishidai); Pühringer, Kallies, 2021 (Paradoxecia kishidai).

FLIGHT PERIOD. The holotype was collected on August $8^{\text {th }}$.

HOST PLANT. Unknown.

DISTRIBUTION. It is only known from the type locality in the province of Hubei, China.

REMARKS. The female is unknown.

Paradoxecia luteocincta Kallies et Arita, 2001

"Paradoxecia luteocincta sp. nov." - Kallies, Arita, 2001 189, 217, fig. 20. Type locality: "N. Vietnam, Ninh Binh Prov., Gia Vien, Cuc Phuong, 370 m, ...” Holotype $q$ (NSMT).

LITERATURE. Pühringer, Kallies, 2004: 7 (Paradoxecia luteocincta); Yu et al., 2019: 268 (key) (Paradoxecia luteocincta); Pühringer, Kallies, 2021 (Paradoxecia luteocincta).

FLIGHT PERIOD. The holotype was collected on April $28^{\text {th }}$.

HOST PLANT. Unknown.

DISTRIBUTION. It is only known from the type locality in North Vietnam.

REMARKS. The male is unknown and the female genitalia have not yet been studied.

Paradoxecia myrmekomorpha (Bryk, 1947)

"Paranthrenina myrmekomorpha m." - Bryk, 1947: 106, Taf. 1, Fig. 9. Type locality: "NO Birma, Kambaiti, 6000 Fs. ..." [= Myanmar: Kachin State, Kambaiti Pass]. Holotype 9 (NRMS).

LITERATURE. Naumann, 1971: 22 (Paranthrenina myrmekomorpha); Heppner, Duckworth, 1981: 24 (Paranthrenina myrmekomorpha); Kallies, Arita, 2001: 189, 215, figs 18, 19, 38 (Paradoxecia myrmekomorpha); Gorbunov, Arita, 2001: 19, figs 5, 6, 27 (Paranthrenina myrmekomorpha); Pühringer, Kallies, 2004: 7 (Paradoxecia myrmekomorpha); Arita, 2011: 37, pl. 3, fig. 23 (Paradoxecia myrmekomorpha); Arita et al., 2018: 8, pl. 1, figs 10, 11 (Paradoxecia myrmekomorpha); Yu et al., 2019: 268 (Paradoxecia myrmekomorpha); Pühringer, Kallies, 2021 (Paradoxecia myrmekomorpha); Arita et al., 2021b: 36, figs 388a-b (Paradoxecia myrmekomorpha).

FLIGHT PERIOD. The holotype was collected on June $8^{\text {th }}$. Specimens from Vietnam were catch in the end of June.

HOST PLANT. Unknown.

DISTRIBUTION. It is known from the type locality in North-eastern Myanmar, South China and North Vietnam.

Paradoxecia polyzona Yu et Kallies, 2019

"Paradoxecia polyzona Yu et Kallies, sp. nov." - Yu et al., 2019: 263, 268 (key), figs 3, 4, 8. Type locality: "China, Tibet autonomous region, Linzhi, Bomi county, Tongmai town, $30^{\circ} 05^{\prime}$



LITERATURE. Pühringer, Kallies, 2021 (Paradoxecia polyzona).

FLIGHT PERIOD. The type series was collected at the end of July.

HOST PLANT. Unknown.

DISTRIBUTION. It is known from Tibet, China.

REMARKS. The female is unknown.

Paradoxecia radiata Kallies, 2002

"Paradoxecia radiata sp. n." - Kallies, 2002: 207, figs 1-4. Type locality: "Sarawak: Mt Dulit. / 4,000 ft. / Moss Forest. ..." [= Malaysia: Sarawak, Mt Dulit]. Holotype + (BMNH).

LITERATURE. Pühringer, Kallies, 2004: 7 (Paradoxecia radiata); Yu et al., 2019: 267 (key) (Paradoxecia radiata); Pühringer, Kallies, 2021 (Paradoxecia radiata).

FLIGHT PERIOD. The holotype was collected on October $24^{\text {th }}$.

HOST PLANT. Unknown.

DISTRIBUTION. It is only known from the type locality on the island of Borneo.

REMARKS. The male is unknown.

Paradoxecia similis Arita et O. Gorbunov, 2001

"Paradoxecia similis sp. nov." - Arita, Gorbunov, 2001: 138, figs 5, 46a-d. Type locality: "Taiwan, Nantou Hsien, Meiyuan, ...”. Holotype $\sigma^{7}$ (NSMT)

LITERATURE. Pühringer, Kallies, 2004: 7 (Paradoxecia similis); Yu et al., 2019: 268 (key) (Paradoxecia similis); Pühringer, Kallies, 2021 (Paradoxecia similis).

FLIGHT PERIOD. Specimens of the type series were collected on July $4^{\text {th }}$ and November $13^{\text {th }}$.

HOST PLANT. Unknown.

DISTRIBUTION. It is known from the island of Taiwan only.

REMARKS. The female is unknown.

Paradoxecia taiwana Arita et O. Gorbunov, 2001

"Paradoxecia taiwana sp. nov." - Arita, Gorbunov, 2001: 135, figs 3, 4, 45a-d. Type locality: "Taiwan, Nantou Hsien, Penpuchi, ca 1,000 m, ...”. Holotype $\sigma^{7}$ (NSMT).

LITERATURE. Pühringer, Kallies, 2004: 7 (Paradoxecia taiwana); Yu et al., 2019: 268 (key) (Paradoxecia taiwana); Pühringer, Kallies, 2021 (Paradoxecia taiwana).

FLIGHT PERIOD. The type series was collected from mid-May to early October.

HOST PLANT. Unknown.

DISTRIBUTION. It is known from the island of Taiwan only.

REMARKS. The female genitalia have not yet been studied.

Paradoxecia tristis Kallies et Arita, 2001

"Paradoxecia tristis sp. nov." - Kallies, Arita, 2001: 221, figs 24, 25, 40, 53. Type locality: "Viet Nam, Prov. Ha Noi, Ha Noi City, ...”. Holotype or (BMNH).

LITERATURE. Pühringer, Kallies, 2004: 7 (Paradoxecia tristis); Yu et al., 2019: 268 (key) (Paradoxecia tristis); Pühringer, Kallies, 2021 (Paradoxecia tristis).

FLIGHT PERIOD. The type series was collected from the end of April to the end of June.

HOST PLANT. Unknown.

DISTRIBUTION. It is only known from two localities in

North Vietnam.

REMARKS

\section{Paradoxecia tuzovi O. Gorbunov, sp.n.}

"Paradoxecia tuzovi O. Gorbunov, sp.n." - present publication, Figs 1-10. Type locality: "W. Malaysia, Pahang, Genting Highland, 800-1000 m, ...". Holotype $\sigma^{7}$ (COGM).

FLIGHT PERIOD. The type series was collected on October $17-23^{\text {th }}$. 
HOST PLANT. Unknown.

DISTRIBUTION. It is known from the type locality in Malaysia.

REMARKS. The female is unknown.

Paradoxecia vietnamica O. Gorbunov et Arita, 1997

"Paradoxecia vietnamica sp. n." - Gorbunov, Arita, 1997: 61 (key), 62, figs 4, 8. Type locality: "Vietnam, Pahia, ..." [= North Vietnam]. Holotype + (MHNG).

LITERATURE. Kallies, Arita, 2001: 189, 217 (Paradoxecia vietnamica); Pühringer, Kallies, 2004: 7 (Paradoxecia vietnamica) Yu et al., 2019: 267 (key) (Paradoxecia vietnamica); Pühringer, Kallies, 2021 (Paradoxecia vietnamica).

FLIGHT PERIOD. The holotype collected on May $24^{\text {th }}$ HOST PLANT. Unknown.

DISTRIBUTION. It is only known from the type locality in North Vietnam.

REMARKS. The male is unknown.

Acknowlwdgements. I express my heartfelt gratitude to my friend Dr. Vasily K. Tuzov (Moscow, Russia) for collecting specimens of this new species. I am indebted to Mr. Vlad V. Proklov (London, England) for carefully checking the English of an advanced draft.

The study was conducted using the equipment of the Joint Usage Center "Instrumental methods in ecology" at the A.N. Severtsov Institute of Ecology and Evolution, Russian Academy of Sciences (Moscow, Russia).

\section{References}

Arita Y. 2011. Sesiidae // Wang M., Kishida Y. (eds.). Moths of Guangdong Nanling National Nature Reserve. Keltern: Goecke \& Evers. P.37-38. Pl.3.

Arita Y., Gorbunov O.G. 1995a. A revision of the genus Heterosphecia Le Cerf, 1916 (Lepidoptera: Sesiidae, Osminiini) // Tinea. Vol.14. No.2. P.131-141.

Arita Y., Gorbunov O.G. 1995b. A review of the genus Macrotarsipus Hampson, [1893] (Lepidoptera, Sesiidae) of the Oriental region // Trans. Lepid. Soc. Jpn. Vol.46. No.2. P.103-111.

Arita Y., Gorbunov O.G. 1995c. Sesiidae of Nepal // Haruta T. (ed.) Moths of Nepal, part 4 // Tinea. Vol.14. Suppl.2. P.194-206. Pls.108, 128.

Arita Y., Gorbunov O.G. 1996a. New and unrecorded clearwing moths of the genus Melittia Hübner, [1819] (Lepidoptera Sesiidae) from Thailand // Trans. Lepid. Soc. Jpn. Vol.47. No.3. P.157-173.

Arita Y., Gorbunov O.G. 1996b. A revision of Ferdinand Le Cerf's clearwing moth types (Lepidoptera, Sesiidae), kept at the Paris Museum. I. The genus Melittia Hübner [1819] in the Oriental and Australian Regions // Jpn. J. syst. Ent. Vol.2. No.2. P.137-187.

Arita Y., Gorbunov O.G. 1998. A revision of Embrik Strand's clearwing moth types (Lepidoptera: Sesiidae) from Taiwan // Chinese J. Ent. Vol.18. P.141-165.

Arita Y., Gorbunov O.G. 2000a. Notes on the tribe Osminiini (Lepidoptera, Sesiidae) from Vietnam, with descriptions of new taxa // Trans. Lepid. Soc. Jpn. Vol.51. No.1. P.49-74.

Arita Y., Gorbunov O.G. 2000b. On the knowledge of the genus Chamanthedon Le Cerf, 1916 (Lepidoptera, Sesiidae, Osminiini) of Vietnam and adjacent countries // Trans. Lepid. Soc. Jpn. Vol.51. No.3. P.205-214

Arita Y., Gorbunov O.G. 2000c. On the tribe Melittiini (Lepidoptera, Sesiidae) of Vietnam // Tinea. Vol.16. No.4. P.252-291.

Arita Y., Gorbunov O.G. 2001a. Sesiidae of Taiwan. I. The tribes Tinthiini, Similipepsini, Paraglosseciini, Pennisetiini, Paranthrenini and Cissuvorini // Jpn. J. syst. Ent. Vol.7. No.2. P.131-188.

Arita Y., Gorbunov O.G. 2002a. A new species of the genus Trichocerota Hampson (Lepidoptera, Sesiidae) from Taiwan. Trans // Lepid. Soc. Jpn. Vol.53. No.4. P.241-244.
Arita Y., Gorbunov O.G. 2002b. Sesiidae of Taiwan. II. The tribes Osminiini, Melittiini and Sesiini // Jpn. J. syst. Ent. Vol.8. No.2. P.199-241.

Arita Y., Gorbunov O.G. 2003. New taxa of wasp-waisted clearwing moths (Lepidoptera, Sesiidae) from Vietnam // Trans. Lepid. Soc. Jpn. Vol.54. No.1. P.11-19.

Arita Y., Gorbunov O.G., Mohamed M. 2003. On the knowledge of the clearwing moth (Lepidoptera, Sesiidae) of the Maliau Basin, Sabah, Borneo // Trans. Lepid. Soc. Jpn. Vol.54. No.2. P.131-142.

Arita Y., Gorbunov O.G., Hsu Y.-F., Kallies A., Liang J.-Y., Huang C.-L., Yata N. 2021a. A taxonomic review of the types of Chinese clearwing moths described by Yang and Wang (Lepidoptera, Sesiidae) // Tinea. Vol.25. No.4. P.305-336.

Arita Y., Gorbunov O.G., Kallies A., Yata N., 2021b. Historical type specimens of Sesiidae species kept in European museums // Tinea. Vol.25. Suppl.3. P.1-211.

Arita Y., Kallies A., Yata N., 2018. Sesiidae// Wang M., Kishida Y., Eda K. (Eds). Moths of Guangdong Nanling National Nature Reserve. Supplement. Hong Kong: Hong Kong Lepidopterists' Society. P.7-14. Pls 1-4.

Arita Y., Kimura M., Owada M. 2009. Two new species of the clearwing moth (Sesiidae) from Okinawa-jima, the Ryukyus // Trans. Lepid. Soc. Jpn. Vol.60. No.3. P.189-192.

Bryk M. 1947. Neue ostasiatische Aegeriiden (Lep.) // Opuscula Entomol. Bd.12. S.96-109.

Dalla Torre K.W., Strand E. 1925. Aegeriidae // Strand E. (Hrsg.). Lepidopterorum Catalogus. Bd.31. Berlin: W. Junk. 202 pp.

Fletcher D.S., Nye I.W.B. 1982. Volume 4. Bombycoidea, Castnioidea, Cossoidea, Mimallonoidea. Sesioidea, Sphingoidea, Zygaenoidea // Nye I.W.B. (ed.). The Generic Names of Moths of the World. London: British Museum (Natural History). 192 pp.

Gaede M. 1933. Family Aegeriidae // Seitz A. (Hrsg.). Die GrossSchmetterlinge der Erde: eine systematische Bearbeitung der bis jetzt bekannten Gross-Schmetterlinge. II. Abteilung - Exotische Fauna. Bd. 10. Die Indo-Australischen Spinner und Schwärmer. Stuttgart: A. Kernen Verlag. S.777-802. Taf.94-95.

Gorbunov O.G. 2014. A new species of the genus Melittia Hübner, 1819 ["1816"] from the island of Lombok, Indonesia // Far Eastern Entomologist. No.284. P.13-18.

Gorbunov O.G. 2015a. A new species of the genus Anthedonella O. Gorbunov et Arita, 1999 from the island of Siberut, Mentawai, Indonesia // Far Eastern Entomologist. No.299. P.11-17.

Gorbunov O.G. 2015b. Clearwing moths (Lepidoptera: Sesiidae) of Laos. I. Akaisphecia melanopuncta O. Gorbunov, Arita, 1995 (Sesiidae: Sesiinae: Osminiini) // Tropical Lepid. Research. Vol.25. No.2. P.98-100.

Gorbunov O.G. 2016. Nokona mahawu sp. n., a new clearwing moth species (Lepidoptera, Sesiidae) from North Sulawesi, Indonesia // Russian Entomol. J. Vol.25. No.2. P.161-165.

Gorbunov O.G. 2018. A new species of the genus Taikona Arita et O. Gorbunov, 2001 from the Malay Peninsula (Lepidoptera, Sesiidae) // Russian Entomol. J. Vol.27. No.3. P.293-296.

Gorbunov O.G. 2020. To the morphology and synonymy of insufficiently known Melittia rutilipes Walker, 1865 ["1864"] (Lepidoptera: Sesiidae) // Russian Entomol. J. Vol.29. No.1. P.87-92.

Gorbunov O.G. 2021a. A new species of the genus Scoliokona Kallies et Arita, 1998 (Lepidoptera: Sesiidae) from Bali, Indonesia with a catalogue of the genus // Russian Entomol. J. Vol.30. No.1. P.93-99.

Gorbunov O.G. 2021b. A new species of the genus Pyrophleps Arita et O. Gorbunov, 2000 (Lepidoptera: Sesiidae) from Laos, with remarks on the genus // Russian Entomol. J. Vol.30. No.2. P.166-174.

Gorbunov O.G. 2021c. Review of the genus Aschistophleps Hampson, 1893 (Lepidoptera, Sesiidae) of Laos // Zootaxa. Vol.5020. No.2. P.384-396.

Gorbunov O.G. 2021d. A new genus of the tribe Osminiini (Lepidoptera: Sesiidae) from the Oriental Region // Far Eastern Entomologist, in press.

Gorbunov O.G., Arita Y. 1995a. A new genus and species of the clearwing moth tribe Osminiini from the Oriental Region (Lepidoptera, Sesiidae) // Trans. Lepid. Soc. Jpn. Vol.46. No.1. P.17-22. 
Gorbunov O.G., Arita Y. 1995b. New and poorly known clearwing moth taxa from Vietnam (Lepidoptera, Sesiidae) // Trans. Lepid. Soc. Jpn. Vol.46. No.2. P.69-90.

Gorbunov O.G., Arita Y. 1995c. New taxa of the tribe Melittiini (Lepidoptera, Sesiidae) from the Oriental Region // Tinea. Vol.14. No.3. P.149-156.

Gorbunov O.G., Arita Y. 1995d. A revision of Frederic Moore's clearwing moth types (Lepidoptera, Sesiidae), at Humboldt University, Berlin // Tinea. Vol.14. No.3. P.204-224.

Gorbunov O.G., Arita Y. 1995e. A revision of Similipepsis violaceus Le Cerf, 1911 with establishment of a new genus from East Asia (Lepidoptera: Sesiidae: Tinthiinae) // Annales Soc. Ent. France (Nouvelle série). Vol.31. No.4. P.377-384.

Gorbunov O.G., Arita Y. 1997. Review of the genus Paradoxecia Hampson, 1919 (Lepidoptera, Sesiidae, Tinthiinae) // Bonner zool. Beitr. Bd.47. Nos.1-2. P.59-68.

Gorbunov O.G., Arita Y. 1999. New taxa of the clearwing moths (Lepidoptera, Sesiidae) from Nepal // Tinea. Vol.16. No.2. P.106-143.

Gorbunov O.G., Arita Y. 2000a. Study on the Synanthedonini (Lepidoptera, Sesiidae) of Vietnam // Jpn. J. syst. Ent. Vol.6. No.1. P.85-113.

Gorbunov O.G., Arita Y. 2000b. A new species of the genus Paranthrenopsis Le Cerf, 1911 (Lepidoptera, Sesiidae) from China // Trans. Lepid. Soc. Jpn. Vol.51. No.3. P.247-250.

Gorbunov O.G., Arita Y. 2001a. A new species of the genus Ravitria Gorbunov, Arita (Lepidoptera, Sesiidae) from Yunnan, China // Trans. Lepid. Soc. Jpn. Vol.52. No.4. P.245-249.

Gorbunov O.G., Arita Y. 2001b. New taxa of Osminiini (Insecta: Lepidoptera: Sesiidae) from China, with establishment of a new subgenus from the Western Palaearctic // Species Diversity. Vol.6. No.4. P.363-376.

Gorbunov O.G., Arita Y. 2001c. A revision of Felix Bryk's clearing [sic] moth types (Lepidoptera, Sesiidae), at the Naturhistoriska Riksmuseet in Stockholm, Sweden // Melittia, Lepidop. Almanac. Vol.1. P.9-51.

Gorbunov O.G., Arita Y. 2002a. A new species of the genus Aschistophleps Hampson (Lepidoptera, Sesiidae) from Vietnam // Trans. Lepid. Soc. Jpn. Vol.53. No.4. P.193-196.

Gorbunov O.G., Arita Y. 2005. A new genus and two new species of Synanthedonini (Lepidoptera, Sesiidae) from the Oriental Region // Tinea. Vol.18. Suppl.3. P.86-95.

Gorbunov O.G., Arita Y. 2015. A new species of the genus Nokona Matsumura, 1931 (Lepidoptera, Sesiidae) from South Sulawesi // Far Eastern Entomologist. No.293 P.1-6.

Gorbunov O.G., Arita Y. 2018a. To the systematic position of Synanthedon subauratus Le Cerf, 1916 (Lepidoptera: Sesiidae) // Russian Entomol. J. Vol.27. No.1. P.55-60.

Gorbunov O.G., Arita Y. 2018b. A new species of the genus Sazonia O. Gorbunov et Arita, 2001 from Vietnam (Lepidoptera: Sesiidae) // Zootaxa. Vol.4527. No.4. P.595-599.

Gorbunov O.G., Arita Y. 2019. A new species of the genus Taikona O. Gorbunov et Arita, 2001 from Vietnam (Lepidoptera: Sesiidae) // Zootaxa. Vol.4624. No.1. P.137-141.

Gorbunov O.G., Arita Y. 2020a. A new species of the genus Toleria Walker, 1865 ["1864"] from Vietnam, with a catalogue of Asian Cissuvorini (Lepidoptera: Sesiidae) // Zootaxa. Vol.4802. No.2. P.349-360.

Gorbunov O.G., Arita Y. 2020b. A new species of the genus Nokona Matsumura, 1931 (Lepidoptera: Sesiidae) from Vietnam // Russian Entomol. J. Vol.29. No.2. P.195-198.

Gorbunov O.G., Arita Y. 2020c. Two new species of the genus Nokona Matsumura, 1931 (Lepidoptera, Sesiidae) from Vietnam // Far Eastern Entomologist. No.412. P.1-12.

Gorbunov O.G., Kallies A. 1998. Two new species of the genus Cyanosesia Gorbunov, Arita, 1995 (Lepidoptera, Sesiidae) from the Oriental Region // Nachr. Ent. Ver. Apollo (N.F.). Suppl.17. P.457-464.

Hampson G.F. 1919. A classification of the Aegeriadae [sic] of the Oriental and Ethiopian Regions // Novitates Zoologicae. Vol.26. No.1. P.46-119.

Heppner J.B., Duckworth W.D. 1981. Classification of the Super- family Sesioidea (Lepidoptera, Ditrysia) // Smithsonian Contr. Zool. Vol.314. P.1-144.

Kallies A. 2002. A new species of the genus Paradoxecia Hampson, 1919 from Borneo (Lepidoptera: Sesiidae, Tinthiinae) // Nachr. Ent. Ver. Apollo (N.F.). Bd.22. No.4. S.207-209.

Kallies A., Arita Y. 1998a. Revision of Paranthrene chrysoidea Zukowsky, 1932 (Lepidoptera, Sesiidae) from Taiwan // Species Diversity. Vol.3. No.2. P.211-217.

Kallies A., Arita Y. 1998b. New and little known clearwing moths (Lepidoptera, Sesiidae) from the Philippine Islands // Trans. Lepid. Soc. Jpn. Vol.49. No.4. P.245-270.

Kallies A., Arita Y. 2001. The Tinthiinae of North Vietnam (Lepidoptera, Sesiidae) // Trans. Lepid. Soc. Jpn. Vol.52. No.3. P.187-235.

Kallies A., Arita Y., Owada M., Wang M. 2014a. Laetosphecia, a new genus of clearwing moths from south-eastern China, with a brief review of the Sesiini from China (Lepidoptera, Sesiidae) // Zootaxa. Vol.3895. No.4. P.581-589.

Kallies A., Arita Y., Owada M., Wu G.-Y., Wang M., 2014. The Paranthrenini of Mainland China (Lepidoptera, Sesiidae) // Zootaxa. Vol.3811. No.2. P.185-206.

Lieu K.O.V. 1935. Study of a new species of Chinese mulberry-borer Paradoxecia pieli n. sp. (Lepidoptera, Aegeriidae) // Notes Ent. Chinoise, Vol.2. No.10. P.185-209. Pls I-V.

Naumann C.M. 1971. Untersuchungen zur Systematik und Phylogenese der holarktischen Sesiiden (Insecta, Lepidoptera) // Bonner Zool. Monographien. Bd.1. S.1-190.

Pühringer F., Kallies A. 2004. Provisional check list of the Sesiidae of the world (Lepidoptera: Ditrysia) // Mitt. Ent. Arb.gem. Salzkammergut. Bd.4. S.1-85.

Pühringer F., Kallies A. 2021. Checklist of the Sesiidae of the world (Lepidoptera: Ditrysia). Available from: http://www.sesiidae.net/ Checklst.htm (accessed 22 May 2021).

Skowron Volponi M. 2019. A new species of spectacular spider wasp mimic from Thailand is the first representative of the genus Melanosphecia Le Cerf 1916 (Lepidoptera: Sesiidae: Osminiini) to be filmed in the wild // Zootaxa. Vol.4695. No.3. P.295-300.

Skowron Volponi M. 2020. A vivid orange new genus and species of Braconid-mimicking clearwing moth (Lepidoptera: Sesiidae) found puddling on Plecoptera exuviae// Insects. Vol.11. No.425. P.1-9.

Skowron M.A., Munisamy B., Hamid S.B.A., Wegrzyn G. 2015. A new species of clearwing moth (Lepidoptera: Sesiidae: Osminiini) from Peninsular Malaysia, exhibiting bee-like morphology and behaviour // Zootaxa. Vol.4032. No.4. P.426-434.

Skowron Volponi M.A., Volponi P. 2017. A new species of waspmimicking clearwing moth from Peninsular Malaysia with DNA barcode and behavioural notes (Lepidoptera, Sesiidae) // ZooKeys. No.692. P.129-139.

Špatenka K., Gorbunov O., Laštùvka Z., Toševski I., Arita Y. 1999. Sesiidae, Clearwing Moths // Naumann C.M. (Ed.). Handbook of Palaearctic Macrolepidoptera. Vol. 1. Wallingford: Gem Publishing Company. 569 pp. 57 Pls.

Špatenka K., Laštùvka Z., Gorbunov O.G., Toševski I., Arita Y. 1993. Die Systematik und Synonymie der paläarktischen Glasflügler-Arten (Lepidoptera, Sesiidae) // Nachr. Ent. Ver. Apollo (N.F.). Vol.14. No.2. P.81-114.

Walker F. 1865 ["1864"]. List of the Specimens of Lepidopterous Insects in the Collection of the British Museum. Supplement 31 (Suppl. 1). London. 321 pp.

Xu H.-M., Arita Y., Chen B., Wang M. 2015. Description of Pyrophleps bicella (Lepidoptera: Sesiidae), a new Chinese species of clearwing moth // Florida Entomologist. Vol.98. No.1. P.149-151.

Xu Z., Jin T., Liu X. 1999. Description of a new species of the genus Sphecosesia Hampson, 1910, from Jiangxi (Lep.: Sesiidae) // Acta Agric. Boreali-occidentalis Sinica. Vol.8. No.2. P.3-5.

Xu Z., Liu X.. Jin T. 2019. Clearwing Moths of China. China Forestry Publishing House. $149 \mathrm{pp}$

Yu T., Arita Y., Kallies A., Wang M. 2019. Three new species of the genus Paradoxecia Hampson, 1919 (Lepidoptera: Sesiidae) from China // Zootaxa. Vol.4691.No.3. P.261-269. 